and Schwarzbard also seems somewhat unpersuasive. The unreserved acclamation of the Ukrainian Jewish avenger as a national Jewish martyr versus the reluctance to adopt Dreyfus as a Jewish hero some thirty years earlier stems from the extraordinary violence of the pogroms of the Civil War, compared by many contemporaries to the Armenian genocide. This exceptional volume brings together some unique sources that remind us of the ambivalent and fragmented nature of the politics of memory in twentieth century Europe, where narratives of victimhood and victimization coexisted, clashed, but rarely intersected.

ELISSA BEMPORAD

Queen's College, the City University of New York

\title{
Poiavlenie geroia: Iz istorii russkoi emotsional'noi kul'tury kontsa XVIII-nachala XIX veka. By Andrei Zorin. Moscow: Novoe Literaturnoe Obozrenie, 2016, 563 pp. Notes. Bibliography. Index. Illustrations. RUB 624, hard bound. doi: 10.1017/slr.2017.211
}

Andrei Zorin has given us yet another page-turner. His latest book is a study of Andrei Ivanovich Turgenev (1781-1803), who lived at a time when the "tradition-oriented" individual, whose values and behavior were based on the rituals and practices of prior generations, was giving way to the "inner-oriented" individual, who endeavored to live his life by principles worked out in his youth (David Riesman, The Lonely Crowd, 2001). How a shift in sociocultural norms brought about in Turgenev an emotional conflict that had a profound effect on his worldview is the subject of this book.

The introduction provides a survey of the psychological, anthropological, and sociocultural theories of the history of emotions, both in European and Russian contexts, and outlines the theoretical underpinnings of the author's approach. A rich bibliography accompanies this survey. Zorin bases his approach on a sociocultural theory of emotion developed by two Dutch psychologists, Nico Frijda and Batja Mesquita, according to whom emotions are social and relational phenomena, which accounts for significant differences in emotional experiences in different cultures. Emotions, generated not so much by an event as by the meaning assigned to it by a specific culture, are inseparable from the sociocultural context that produces emotional matrixes. Emotional experience-emotional process-consists in "event coding," "appraisal," and "action readiness." The study of emotional process becomes a matter of cultural history, because its ingredients depend on a particular sociocultural context.

Setting the stage for the analysis of Turgenev's emotional experience, Zorin offers several examples of emotional culture at the end of the eighteenth century-the time of Turgenev's coming of age. Chapter 1 juxtaposes emotional matrixes developed at Catherine's court and orchestrated by the empress herself to alternative symbolic models of the senses worked out by the Moscow circle of Rosicrucians, one of whose leaders was Turgenev's father, Ivan Turgenev.

The matrixes of the sentimental education for her courtiers and others close to the court emanated from the empress: the court theater, whose most authoritative dramatist she was, instilled patterns of feelings that, although coming from the outside, were supposed to be interiorized by the viewers and produce desirable behavior.

For Rosicrucians, the idea of emotional education led in the opposite direction. Rejecting theater as an example for imitation, they turned to reading, interpreting, and translating esoteric and moral-didactic literature for self-edification and, in the long run, for the benefit of the public. They developed a ritual of writing confessional 
diaries and letters, the aim of which was to "know thyself and improve." The center of authority in their worldview shifted from the monarch and official church to the secret Rosicrucian hierarchy.

These two different types of "emotional community" (Barbara Rosenwein, Emotional Community in the Early Middle Ages, 2006), with one presided over by an autocrat, inevitably came to blows. Chapter 2 discusses the formation of a new "emotional community" as the Russian educated public turned to European sentimentalist literature as the main source for its emotional repertoire. Zorin analyzes Karamzin's Letters of the Russian Traveler as a new kind of diary whose emotional center resides in the diarist himself. Inspired by Nikolai Karamzin, Michail Muraviev left a diary in the form of letters. Muraviev straddled two "emotional communities"-court bureaucracy and the readership of sentimentalist literature. His emotional experiences and responses depended on which hat he wore at the time.

As the last case, before turning to Turgenev, Zorin considers Aleksandr Radishchev's Diary of One Week and literary antecedents for his suicide: his identification with the emotional states of Joseph Addison's high tragedy protagonist in Cato, and a hero of Bernard-Joseph Saurin's 1768 bourgeois drama Béverlei. Educated Russians were ready to learn to feel according to the European symbolic literary emotional matrixes. This can be observed best from personal diaries, in which "I" looks at "me."

Chapters 3 through 6 tell the main story of the book: Turgenev's emotional life as seen through his diary, from November 1799 to his death (suicide?) in 1803. Brought up by one emotional community, that represented by his father, Turgenev had become a leader of another-the admirers of German literature who formed themselves into a Friendly Literary Society. He had to negotiate the legacy of the one having internalized the essence of the other. As a key to Turgenev's diary, built on literary models and written in search of rules suitable for preserving Selbstheit (as Turgenev put it), Zorin applies a sociocultural model that enables him to approach emotional processes of a single individual in a specific culture.

LINA BERNSTEIN

Franklin \& Marshall Colleges

Siblings in Tolstoy and Dostoevsky: The Path to Universal Brotherhood. By Anna A. Berman. Studies in Russian Literature and Theory. Evanston: Northwestern University Press, 2015. xvi, 242 pp. Notes. Bibliography. Index. Paper, \$39.95. doi: 10.1017/slr.2017.212

Anna Berman's rich and engaging study of the family novels of Tolstoi and Dostoevskii shifts the usual critical focus from erotic love or intergenerational conflict to siblinghood, tracing the trajectories of both writers as they seek to negotiate the question of love through the polyvalent concept of brotherhood. Building on Juliet Mitchell's work, Berman refocuses our frame of reference from the vertical relations of the family to horizontal or lateral ones (6). In the case of Tolstoi, she sees his fiction as unfolding according to the three phases of love which he later universalized in The Kingdom of God is within You as "the personal, or animal," "the social, or the pagan," and "the universal, or the divine” (26). His early works explore love's personal aspect, culminating in the ideal families of the end of War and Peace; Anna Karenina embodies the tensions of the second, social, stage; and Resurrection marks the all-encompassing concept of divine and universal brotherhood encapsulated in Tolstoi's recollection of his brother's dream of all mankind as Ant-brothers, a model which ultimately 